系下盛溶加棒の採用により第二層目肉盛溶接部中に移行 する傾问が諗められた。また，いずれの溶加棒を用いた 場合においてす，ほとんどの割れはフィルム状の Cr 炭 化物の存在する結晶粒界を起点として発生している。

（2）肉盛溶接部の第一首目及び第二層目の粒界炭化物 幅は下盛溶加棒中の Cr 量汃低下するにつれ，また， $\mathrm{Zr}$ 添加量功増すにつれ減少する。

(3) $\mathrm{Zr}$ 添加低 $\mathrm{Cr}$ 系下盛溶加棒を用いた第一風目肉 盛溶接部 PWHT 材におけるAW材の硬さからの上昇の 程度は $30 \mathrm{Cr}-2 \mathrm{M}$ 鋼溶加棒を用いた第一㬝目肉盛浴接 部のそれよりも小さい，とのことから，肉盛溶接部の PWHT による硬化上対応関係にあると考えられる $475^{\circ} \mathrm{C}$ 脆化息 $\mathrm{Zr}$ 添加低 $\mathrm{Cr}$ 系下盛溶加棒を用いた第一首目肉 盛溶接部では軽減されているものと推察された。

(4) 第一風目肉盛溶接部の界面近傍の平均の結晶粒径 は下盛溶加棒の $\mathrm{Zr}$ 添加量の增加に伴い微細化する傾向 を示した。

(5) 下盛溶加棒の $\mathrm{Zr}$ 添加低 $\mathrm{Cr}$ 化による曲げ延性改 善には粒界炭化物幅の減少の寄与が最も大きく，ついで 結晶粒の微紐化手有效に作用しているととが判明した。 その他, 低 $\mathrm{Cr}$ 化による $475^{\circ} \mathrm{C}$ 脆化の軽減む曲げ延性改
善に寄与している6のと推察された。

また，乙の場合の粒界炭化物幅减少の理由として，下 盛溶加棒の低 $\mathrm{Cr}$ 化によって固溶 $\mathrm{C}$ 量が増加すること， ならび Zr 添加によって ZrC が優先析出するととに 起因して，粒界炭化物の形成に消費される $\mathrm{C}$ 量が減少す るこよ及び結晶粒微紐化による粒界面積の増加による効 果が洘えられた。

\section{参考 文 献}

1) 中尾, 西本, 辰 $\mathrm{E}$, 野井, 塚原, 原, “肉盛溶接部の脆化現 象”，溶接学会論文集，Vol.4(1986)，No.3, p.527-533

2) 中尾，西本，山崎，野井，琭原，原，“肉盛溶接部の脆化機 棈”, 溶接学会論文集, Vol.5(1987), No.3, p.422-429

3) 中尾, 西本, 山崎, 野卉, 塚原, 原, “肉盛溶接部の曲げ延性改 塞方策", 溶接学会論文集, 投稿中

4) 野井, “高純度フェライト系ステンレスクラッド鋼の溶接に関す る研究", 大阪大学学位請求論文(1988)

5) 今井, 西野, 中川, “ $475^{\circ} \mathrm{C}$ 脆化した $\mathrm{Fe}-\mathrm{Cr}$ 合金の機械的性 質”, 日本金属学会誌，Vol.29(I965)，No.4，p.346-350

6) T. J. Nichol, A. Datta and G. Aggen, "Embrittlement of ferritic stainless steels", Metallurgical Transactions A. Vol. 11A(1980), Apr., p.573-585

\title{
接合界面におけるめっき層の組織と接合性に 及ぼすめっき浴組成の影響*
}

ーマイクロパラレルシーム接合法とその接合機器の䦎発(第 3 報)一

$$
\text { 青野 進**大森 幸一***伊藤 愿*** }
$$

Influence of Bath Constituent on Microstructure and Joining

Characteristics of Plating Layer at the Joining Interface

-Micro-Parallel Seam Joining and Development of Joining Equipment (3rd Report)-

$$
\text { by Susumu Aono**, Kouichi Ohmori***, Atsushi Ito**** }
$$

Experimental evaluation of hermeticity and joining strength and an investigation of joints by SEM, EPMA, AES, were accomplished on hermetically sealed package by Micro-Parallel Seam Joining (MPSJ) using a lid (Fe-Ni-Co alloy) normally applied as hermetic seal of ceramic package for highly reliable LSI, nickel plated in both Watts Bath and Sulfamate Bath. The results are summarized as follows.

(1) Crack was observed at the grain boundary in a plating layer at the joining interface of ceramic package which was hermetically sealed with use of nickle plated lid in a Sulfamate Bath. The crack is considered to be caused by sulfur segregation at the grain boundary from the result of investigation by SEM and AES. As a result, both hermeticity and joining strength were unsatisfactory.

(2) Tendency of crack occurrence was observed to be especially notable at the seam joint after thermal cycling test performed to evaluate reliability of joint rather than immediately after joining. Therefore, thermal cycling test is considered to be an effective means for evaluation of crack occurrence.

(3) Crack was not observed at the joining interface of hermetically sealed package using nickel plated lid in a Watts Bath and indicated to be a sound joint structure. Both hermeticity and joining strength were resulted to be satisfactory. However, peeling of plated layer at an area of the lid slightly away from the joining section was observed on a lid applied with thick plating of $10 \mu \mathrm{m}$. Therefore, plating thickness of approximately $3.5 \mu \mathrm{m}$ in a Watts Bath is considered to be adequate.

\footnotetext{
*原稿受付 昭和 63 年 3 月18日 昭和 62 年2月マイクロ接合研究委員 会で発表

**正 員 日本アビオニクス(株) Member, Nippon Avionics Co.,Ltd.

***日本アビオニクス(秼) Nippon Avionics Co,Ltd
} 
(4) Correlation between hermeticity and peel strength was not found on package hermetically sealed with use of nickel plated lid in a Sulfamate Bath. Although specified value for hermeticity was satisfied, peel strength was zero or a value close to zero on some specimens. Therefore, both methods are required to be performed as an evaluation method for joint of hermetically sealed package by MPSJ method.

Key Words: Ceramic Package, Nickel Plating Layer, Plating Bath Constituent, Sulfur Segregation, Grain Boundary Cracking, Hermeticity, Peel Strength

\section{1. 緒空}

前報に捖いで，マイクロパラレルシーム接合法（以 下 MPSJ と略す) によりセラミックパッケージを気密 封止する绩合，シーム接合現象の観点から規定の気密度 を碓保するためには，めっきが重要な役割を果たすこ 亡，及び特に燐を含を無電解ニッケルめっきは，接合界 面に制れが発生し気密度を覀化させる原因上なるので， 電解ニッケルめっきが推癸されていることなどを報告し た．しかし電解めっきにおいても，めっき液の浴組成と 気密度，シ一么接合強さなどの気密封止特性との関係を 調査した結果，めっき浴組成によっては規定の気滵度を 確保するととができず，シーム接合強さす著しく低下す ることが判朋した：またてれら致密封止特性不良のシー 么接合部を光爫顕微鏡，SEM，EPMA，AESなどによ り調查，分析した結果，接合界面におけるめっき層の結 昆粒界に硫黄の偏析が原因と考えられる微細な割れが観 察され，乙れが気密封止特性の不良原因であることを明 らかにした，さらに気密封止に関する俨価基準しして規 格に筀められた気密度とシーム接合強さとの間には相関 関係は認められず，気密度は規格值を確保されれている パッケージにおいても，そのシ一ム接合强さは㤋でな いあのがあるとよが判明した。したがって MPSJによ り疑密封止された高信頼性 LSI 用セラミックパッケー ジのシーム接合部に対する評洒項目としては両者を併用 する必要のあることを提案した。

\section{2. 実験方法及び実験装置}

実験に使用した接合方法，接合材料及び接合条件を Table 1 に示す。まず, 予備実験としてパソレルギャッ プ接合法 (Parallel gap joining, 以下 PGJと略す) を用 い，短時間通電による急熱，急冷効果が接合界面におけ るめっき組織に及ぼす影響について調査した。

PGJは，シリーズ抵抗溶接法の一種で，リボン材に 2 本の電極をあて，一定の加圧力で加圧しながら電極間 に電流を流してりボン材と薄板を接合するあのである。 Table 1 に示す接合条件は，両材料がめっき風を介して 接合するよう設定し，母材同志の直接接合は極力避ける 条件とした，その理由は PGJ による電極直下のめっき 囷の接合組織変化を明確に観察するためである，接合装 固は通常の単相交流式抵抗 スポット溶接装置を使用し た。なお MPSJについては，前報りと同じ方法，装置を 使用したので省略する。

次にめっき材料，めっき浴組成及びめっき条件を Table 2 に示すが，乙れら各種のめっき条件は Table 1 の Thin plate 及び Lid に対して夷施したむのであり, Ribbon 及び Package のめっきは Table 3 のワット浴に よるニッケルめっきを下地とする金めっきのみとした。 Table 2 において、ニッケルめっき液としてワット浴 （硫酸ニッケル一塭化ニッケルーほう酸浴）を使用した 理由は，ニッケルめっき液の浴組紻として代表的なむの であり，またニッケルイオンの供給源である硫酸ニッケ

Table 1 Joining methods, materials and conditions

\begin{tabular}{|c|c|c|c|c|}
\hline $\begin{array}{l}\text { Joining } \\
\text { conditions } \\
\text { methods }\end{array}$ & \multicolumn{2}{|c|}{$\begin{array}{l}\text { Parallel gap joining } \\
\text { (PGJ) }\end{array}$} & \multicolumn{2}{|c|}{$\begin{array}{c}\text { Micro parallel seam joining } \\
\text { (MPSJ) }\end{array}$} \\
\hline $\begin{array}{l}\text { Materials } \\
\text { to be joined }\end{array}$ & $\begin{array}{r}\text { Ribbon ; Kovar ( } F \\
\text { plated by go } \\
\text { coated with } \\
0.05^{t} \times 0.3^{\mathrm{w}} \mathrm{x} \\
\text { Thin plate; Kovar } \\
\text { plated by go } \\
0.12^{\mathrm{t}} \times 12.8 \mathrm{~s} \\
\text { (Same materi } \\
\text { next column }\end{array}$ & & $\begin{array}{l}\text { Package ; Alumina ceram } \\
\text { Seal frame ; Kovar (Fe-Ni } \\
\text { plated by gold (unde } \\
\text { coated with nickel) } \\
\text { Square type, } 0.5^{\prime} \times 1 \\
\text { Lid; Kovar (Fe-Ni-Co), pl } \\
\text { gold and nickel. } \\
0.12^{t} \times 12.8 \mathrm{sq}\end{array}$ & o) \\
\hline $\begin{array}{l}\text { Joining } \\
\text { conditions }\end{array}$ & $\begin{array}{l}\text { Current } \\
\text { Joining time } \\
\text { Joining force } \\
\text { Electrode material } \\
\text { Electrode gap }\end{array}$ & $\begin{array}{r}300 \mathrm{~A} \\
0.06 \mathrm{~s} \\
19.6 \mathrm{~N} \\
\mathrm{Cu}-\mathrm{Cr} \\
1.0 \mathrm{~mm}\end{array}$ & $\begin{array}{l}\text { Current } \\
\text { Joining time } \\
\text { Cool time } \\
\text { Secondary voltage } \\
\text { Joining force } \\
\text { Electrode material } \\
\text { Electrode gap } \\
\text { Taper angle of electrode } \\
\text { Joining speed }\end{array}$ & $\begin{array}{r}180 \mathrm{~A} \\
0.02 \mathrm{~s} \\
0.04 \mathrm{~s} \\
3.2 \mathrm{~V} \\
6.86 \mathrm{~N} \\
\mathrm{Cu}-\mathrm{Be}-\mathrm{Zr} \\
12 \mathrm{~mm} \\
0.26 \mathrm{rad} \\
3.5 \mathrm{~mm} / \mathrm{s}\end{array}$ \\
\hline
\end{tabular}


Table 2 Plating materials, bath constituents, operating conditions and thickness of deposits

\begin{tabular}{|c|c|c|c|c|c|c|}
\hline $\begin{array}{l}\text { Plating } \\
\text { materials }\end{array}$ & $\begin{array}{l}\text { Plating } \\
\text { baths }\end{array}$ & \multicolumn{2}{|c|}{ Bath constituents } & \multicolumn{2}{|c|}{ Operating conditions } & $\begin{array}{l}\text { Thickness } \\
\text { of deposits }\end{array}$ \\
\hline \multirow{2}{*}{ Nickel } & Watts bath & $\begin{array}{l}\text { Nickel sulfate } \\
\left.\text { (NiSO } 4 \cdot 6 \mathrm{H}_{2} \mathrm{O}\right) \\
\text { Nickel chloride } \\
\left.\text { (Nicl2 } \cdot 6 \mathrm{H}_{2} \mathrm{O}\right) \\
\text { Boric acid } \\
\text { (H2BO3) } \\
\text { Anti-pitting agent } \\
\quad \mathrm{PH}\end{array}$ & $\begin{array}{r}280 \mathrm{~g} / 1 \\
50 \mathrm{~g} / 1 \\
50 \mathrm{~g} / 1 \\
0.05 \% \\
4.0 \sim 4.5\end{array}$ & $\begin{array}{l}\text { Current density } \\
\qquad \\
\text { Temperature }\end{array}$ & $\begin{array}{c}2 \sim 3 A / \mathrm{dm}^{2} \\
5 " 1 \\
323 \mathrm{~K}\end{array}$ & $\begin{array}{l}\text { 1.0, 3.5, } \\
10.0 \mu \mathrm{m}\end{array}$ \\
\hline & $\begin{array}{l}\text { Sulfamate } \\
\text { bath }\end{array}$ & $\begin{array}{l}\text { Nickel sulfamate } \\
{\left[\mathrm{Ni}\left(\mathrm{NH} \mathrm{H}_{2} \mathrm{SO}_{2}\right) 2 \mathrm{H} \mathrm{H}_{2} \mathrm{O}\right]} \\
\text { Nickel chloride } \\
\left.\text { (Nicl2 } \cdot 6 \mathrm{H}_{2} \mathrm{O}\right) \\
\text { Boric acid } \\
\text { (H2BO3) } \\
\text { Anti-pitting agent } \\
\mathrm{PH}\end{array}$ & $\begin{array}{r}600 \mathrm{~g} / 1 \\
5 \mathrm{~g} / 1 \\
40 \mathrm{~g} / 1 \\
0.05 \% \\
4.0 \sim 4.5\end{array}$ & $\begin{array}{l}\text { Current density } \\
\text { Temperature }\end{array}$ & $\begin{array}{c}2 \sim 3 A / \mathrm{dm}^{2} \\
5 n \\
10 " \\
323 \mathrm{~K}\end{array}$ & $\begin{array}{l}1.0,3.5 \\
10,0 \mu \mathrm{m}\end{array}$ \\
\hline Gold. & $\begin{array}{l}\text { Neutral } \\
\text { bath }\end{array}$ & $\begin{array}{l}\text { Gold potassium cyan } \\
{[\mathrm{KAu}(\mathrm{CN}) 2]} \\
\text { Potassium cyanide } \\
\text { (KCN) } \\
\text { Potassium cițrate } \\
\left.\text { (CsHsO7K3 } \cdot \mathrm{HzO}_{2}\right) \\
\mathrm{PH}\end{array}$ & $\begin{array}{l}14 \mathrm{~g} / 1 \\
6.8 \sim \overline{7.2}\end{array}$ & $\begin{array}{l}\text { Current density } \\
\text { Temperature }\end{array}$ & $\begin{array}{r}0.5 \mathrm{~A} / \mathrm{dm}^{2} \\
323 \mathrm{~K}\end{array}$ & $1.0 \mu \mathrm{m}$ \\
\hline
\end{tabular}

ルが安価であることなどのためである。またスルファミ ン酸浴（スルファミン酸ニッケルー塭化ニッケルーほう 酸浴）は，ワット浴に比較して高速めっきが可能である とと，及びめっき層の内部応力がワット浴の半分程度 の $69 \mathrm{MPa}$ とさいととなどの特徴を有するためであ る2,3). とれら二種類のめっき浴には，めっき組織に影

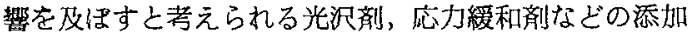
物は加えず，まためっき条件む標準的な值を用いた。な お雨浴と屯電流密度として標準值の $1 \sim 5$ 倍の值を使用 して実験しているが，乙れは特に後述の接合部におりる 割れ発生の原因之考えられる硫黄の含有量に及ぼす影晋 を調查するためである。

シーム接合部の評価方法としては, 気密度試験 $(\mathrm{He}$ ファインリーク法 $)^{4)}$, ピール強さ試験, 接合部の光学顕 微鏡，走查電顕（以下 SEM 上略す）による組織観察の ほか, 電子プローブマイクロアナリシス (EPMA)，エネ ルギー分散 $\mathrm{X}$ 線分光法 $(\mathrm{EDX})$ ，オージェ電子分光法 (AES) などによる表面分析を実施した。これらの結 果 からめっき浴組成上上記評価項目との関係並びに気密度 試験とピール強さ試験との関連などに特に着目して謂 查, 検討を行った。

ピール強さ試験に用いた試験片は Fig.1 亿示す方法 により作成した．まず MPSJにより気密封止されたふ たを, Fig. 1(a) に示すとおり 4 個 ( I 〜 IV) の $3.0 \times 6.4$ $\mathrm{mm}$ の大きさの試験片に分割した後，てれらをピール試 験を実施するためシーム接合部の所で $90^{\circ}$ に折り曲げ (Fig. 1(b) 参照)，その先端部に試験機の千ャック部に装 着するため, 直径 $0.6 \mathrm{~mm}$, 長さ $100 \mathrm{~mm}$ のステンレス 線をスポット溶接した。ピール試験には Instron 1125 万 能試験機を使用し, 引張り速度は $1 \mathrm{~mm} / \mathrm{min}$ 一定とし た.なおピール試験片の幅を $3 \mathrm{~mm}$ と決めた理由は， 予備実験に拉いてとれ以上幅を広くするとシールフレー ムとセラミック基板の間で剝離するものがあり，それ以

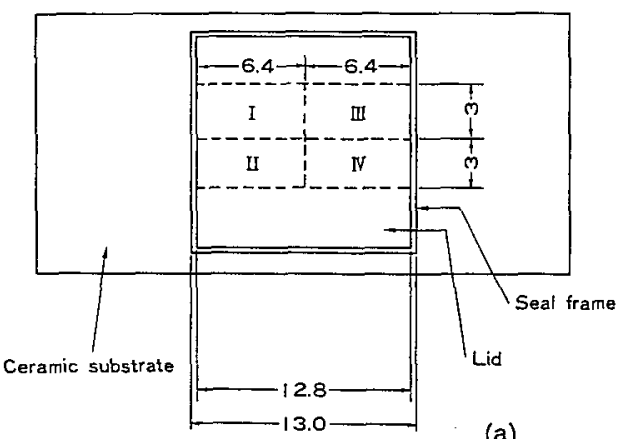

(a)

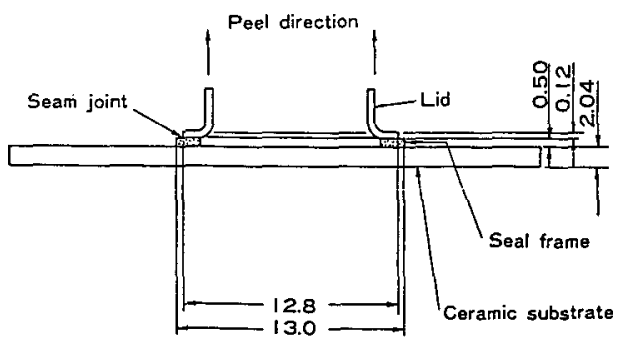

(b)

Fig. 1 Preparation for test pieces (a) and peel test method (b)

後の試験が続行できなくなるためである，またピール試 験の良, 不良の判定基準としては，接合部において剥離 破断しないことを前提に $49 \mathrm{~N}$ と定めた。 


\section{3. 実験結果及び考察}

\section{3-1 PGJ における接合部の特性}

ニッケルめっき液としてスルファミン酸浴を使用し基 準のめっき条件のむとでめっきされた薄板とリボン材を 接合した場合, Fig. 2, 3 に示すとおりその接合部におけ るめっき層の結晶粒界に割れが認められた．Fig. 2 は光 学顕微鏡による断面写真であり, Fig. 3 はリボン材を剝 離したあとの薄板表面の SEM である。このような現象 は, 志田ほかの実験結果と一致する ${ }^{5)}$. この割れ発生の原 因を調べるため, 剥離面を AES により元素分析を行っ た結果, Fig. 4(a) に示すとおり硫黄のスペクトルが珰め られた.との硫黄のスペクトルと, Table 2 に示す三種 類の異なる電流密度との間には特に顕著な差は認められ なかった。ささらに AES の分析装置内において, 赤外線 ランプにより PGJ される前のニッケルめっきされた薄 板表面（電流密度は標準の $3 \mathrm{~A} / \mathrm{dm}^{2}$ ) を加熱したものに ついて調査した結果, Fig. 4(b) に示すとおり特に硫黄の スペクトルが顕著であった。したがって，Fig. 2, 3 に示 すように, PGJにより接合されたリボン材と薄板の接合 部断面の光学顕微鏡写真及び接合部の剝離表面の SEM にみられる割れの発生原因は, めっき工程中に二ッケル とともに電析した硫黄の粒界偏析によるものと考えられ $ろ^{6)}$.

ここで硫黄がなぜニッケルめっき層に電析したかの理 由については, 例えば Greene は, スルファミン酸ニッ ケル溶液中での電気めっきにおいて, 陽極が分極したり 不活性な部分ができると, 次に示す反応式により陽極酸 化生成物であるアゾジスルフォネート（azodisulfonate,

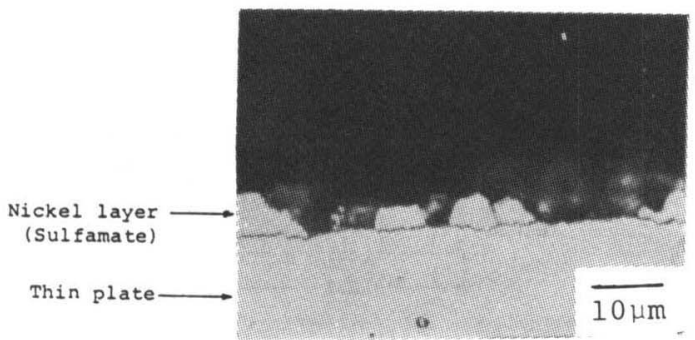

Fig. 2 Cross-sectional microstructure of fractured joint (Sulfamate bath)

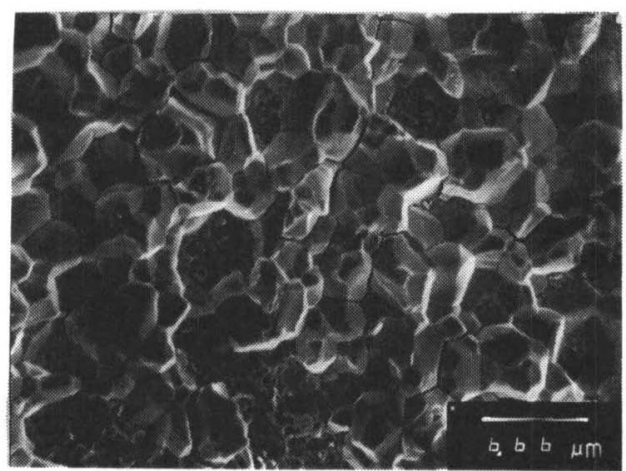

Fig. 3 Scanning electron micrograph of fractured surfc surface (Sulfamate bath)
$\mathrm{ADS}$, 硫黄化合物) が生成されることを紫外線分光光度 分析により確認し, この ADS が硫黄の主要な供給源で あることをつきとめている7).

$$
2 \mathrm{H}_{2} \mathrm{NS}_{3}^{-} \rightarrow \mathrm{SO}_{3} \mathrm{~N}=\mathrm{NSO}_{3}^{=}+4 \mathrm{H}^{+}+4 e
$$

(ADS)

さらにその論文において，乙の硫黄はめっき層の内部 応力と密接な関係をもち, 硫黄の増加とともに内部応力 が減少することを他の研究者らの報告書をあ引用しなが ら説明している。これらの事実から，さきにスルファミ ン酸ニッケル浴を本実験に採用した理由のひとつとし て, ワット浴に比して内部応力の小さいニッケルめっき

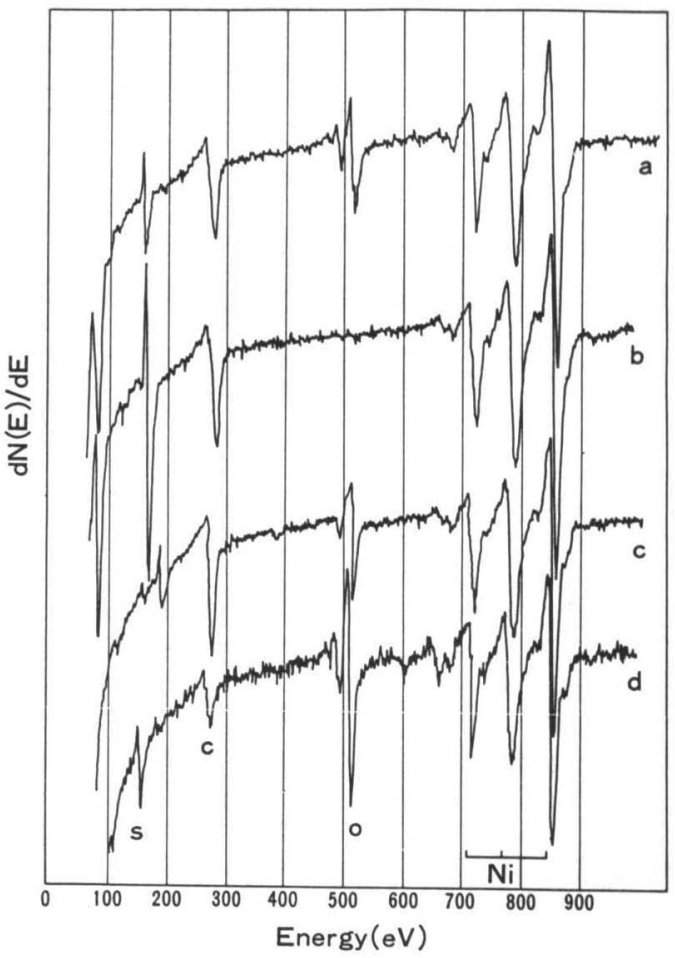

Fig. 4 Auger electron spectra of thin plate surfaces and fractured join surface

(a) Thin plate surface (Sulfamate bath)

(b) Heated thin plate surface (Sulfamate bath)

(c) Thin plate surface (Watts bath)

(d) Fractured joint surface (Sulfamate bath)

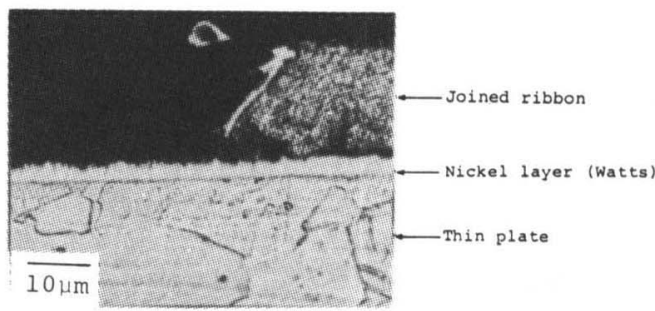

Fig. 5 Cross-sectional microstructure of fractured joint (Watts bath) 
Table 3 Relation between plaiing material, methods, thickness and various seam joning characteristics.

\begin{tabular}{|c|c|c|c|c|c|c|}
\hline \multicolumn{3}{|c|}{$\begin{array}{l}\text { Plating material, } \\
\text { method and thickness }\end{array}$} & $\begin{array}{l}\text { Hermeticity } \\
\text { as seam } \\
\text { joined } \\
\left(\mathrm{Pa} \mathrm{m}^{3} / \mathrm{s}\right)\end{array}$ & $\begin{array}{l}\text { Hermeticity } \\
\text { after thermal } \\
\text { cycle test } \\
\left(\mathrm{Pa} \mathrm{m}^{3} / \mathrm{s}\right)\end{array}$ & $\begin{array}{l}\text { Peel force } \\
\text { as seam } \\
\text { joined } \\
(\mathrm{N})\end{array}$ & $\begin{array}{l}\text { Peel force } \\
\text { after thermal } \\
\text { cycle test } \\
\text { (N) }\end{array}$ \\
\hline \multirow{4}{*}{ Nickel } & \multirow{2}{*}{$\begin{array}{l}\text { Watts } \\
\text { bath }\end{array}$} & $3.5 \sim 5.0(\mu \mathrm{m})$ & $8 \times 10$ & $1 \times 10^{2}$ & $92.1 \%$ & $81.3 \%$ \\
\hline & & $9.0 \sim 10.0(\mu \mathrm{m})$ & $1 \times 10^{2}$ & $1 \times 10^{2}$ & $83.3 \%$ & $68.6^{*}$ \\
\hline & \multirow{2}{*}{$\begin{array}{l}\text { Sulfamate } \\
\text { bath }\end{array}$} & $3.5 \sim 5.0(\mu \mathrm{m})$ & $9 \times 10$ & $1 \times 10^{2}$ & $30.4^{\Delta}$ & $14.7^{\Delta}$ \\
\hline & & $9.0 \sim 10.0(\mu \mathrm{m})$ & $2 \times 10^{3}$ & $2.6 \times 10^{6}$ & $12.7^{\Delta}$ & $0 \Delta$ \\
\hline
\end{tabular}

* Broken at any other area than seam joint.

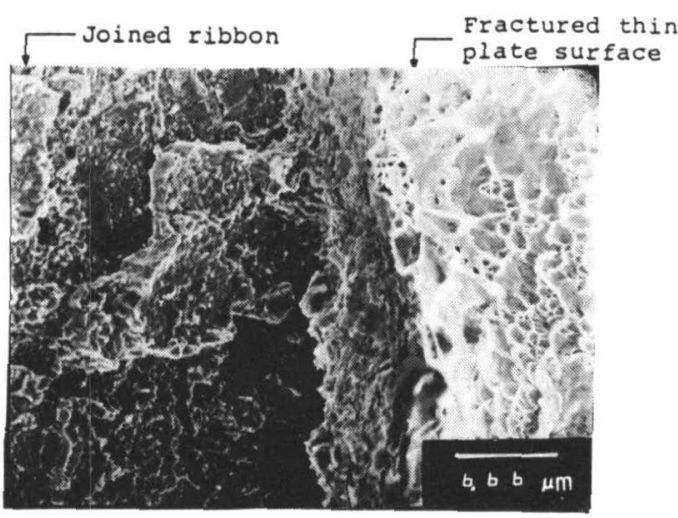

Fig. 6 Scanning electron micrograph of fractured joint surface (Watts bath)

が可能である特徴を有するためとしたが, この特徽が硫 黄の存在に基づくあのであると同時に, その一方におい ては PGJ における割れ発生という久陥の主要な原因 とあなったものと考えられる。

一方，ワット浴については，めっき層における割れの 発生及び AES による顕著な硫黄のスペクトルは珰めら れなかった（Fig.4(c)，5参照).また㓦離面についても スルファミン酸浴でニッケルめっきされた場合に観察さ れた脆性破面と暴なる延性破面を示し, 強固な接合が行 われたてとを示している (Fig. 6 参照).

なお，素材中に含まれる元素の二ッケルめっき層への 㹡散について, 接合部を中心に EPMA により調査した が特に検出できなかった。したがって割れ発生の原因 は, ニッケルめっき層の結晶粒界における硫黄の偏析に よるあのと考えられる。

\section{3-2 MPSJ における接合部の気密封止特性}

次に MPSJ により Table 1 に示す接合条件により気 密封止したセラミックパッケージについて, まず気密度 と接合部のピール強さなどの気密封止特性について調査 した. その結果を Table 3 に示す. なお Table 3 の結果 は, Table 2 に示しためっき条件のうち, 電流密度は ワット浴，スルファミン酸浴ともに2 3 A/ $\mathrm{dm}^{2}$ の標準
$\Delta$ Broken at seam joint.

值によりニッケルめっきされたふたに対して行った実験 結果である，その他の電流密度によりめっきされたふた についても, 気密度, ピール試験などの気密封止特性を 調査したが, Table 3 に示された結果と大きな差は認め られなかった、したがって以下の実験にはすべて標準の 電流密度によりニッケルめっきされたふたを使用した。

Table 3 において, ワット浴に関しては, その気密度 はめっき首の厚さが $3.5 \mu \mathrm{m}, 10 \mu \mathrm{m}$ いずれについても 接合直後及び熱サイクル試験（208〜 423 K 10サイクル） 後において規格值 $\left(10^{3} \mathrm{~Pa} \mathrm{~m} \mathrm{~m}^{3} / \mathrm{s}\right)$ をクリアしている. ま た Fig. 1 に示すピール陚験の結果, いずれのめっき厚さ についても本実験において基準值と定めた $49 \mathrm{~N}$ 以上の 接合強さを得ている.

一方スルファミン酸浴については, $3.5 \mu \mathrm{m}$ のめっき 厚さの屯のは接合直後の気密度は規格值をクリアしてい るが，ピール試験においては試験片 4 個中 1 個はピール 強さがゼロで, 接合強さは不良となっている。 また熱サ イクル試験後の気密度は良好であるが, ピール武験にお いては武験片 4 個中 2 個のピール強さはゼロで接合不良 となった．まためっきの厚さが $10 \mu \mathrm{m}$ のものは，接合 直後の気密度は良好であったが, ピール武験片 4 個中 2 個の接合強さはゼロとなり，接合不良となっている。さ らに熱サイクル陚験後の気密度は $2.6 \times 10^{6} \mathrm{~Pa} \mathrm{~m} / \mathrm{s}$ て 規格值をクリアできず，またピール試験の結果は，試験 片 4 個すべてのピール強さがゼロとなった。

このスルファミン酸浴によりニッケルめっさされたふ たを使用して気密封止されたパッケージの気密度及び ピール接合強さの不良原因を調べるため，シーム接合部 断面の光学顕微鏡による観察及び EPMA による元素分 析を行うとともに，接合部の剥離面を SEM 及び AES により調査した. Fig. 7 にピール 試験前後のふた及び シールフレームの断面写真を示す. との写真から明らか なとおり, Table 3 に示したスルファミン酸浴における 気密度及びピール強さの不良原因は, ニッケルめっき層 内に発生した微紐な割れによるあのであり, 特にピール 強さの不良原因は，めっき㟄における剝離破断によるも のであることを明確に示している. なお Fig. 7(a) のスル ファミン酸浴によるニッケルめっき層内の黒い介在物及 びふた素材とニッケルめっき圈の境界部を SEM/EDX で調査した結果, 硫黄が検出された. 


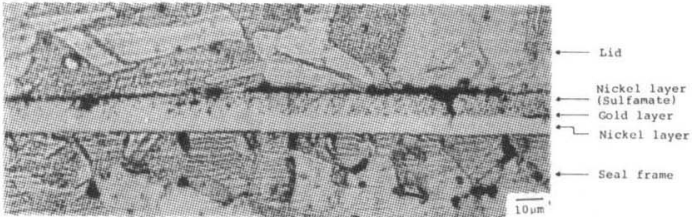

(a)

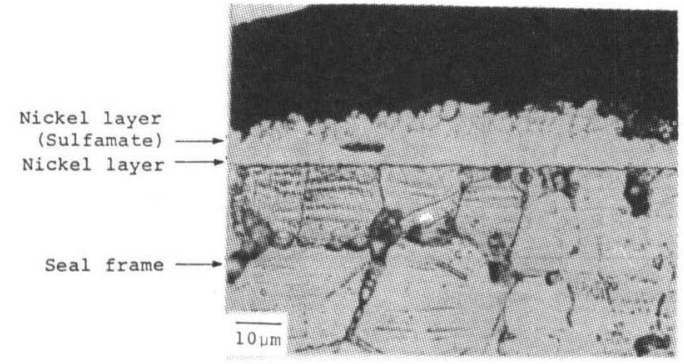

(b)

Fig. 7 Cross-sectional microstructures of joint (Sulfamate bath)

(a) Before peel test

(b) After peel test.

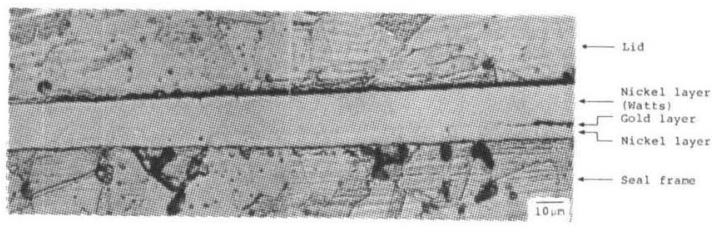

Fig. 8 Cross sectional microstructure of joint (Waits bath)

またピール試験において剝離破断した破面を SEM に より観察した結果，ふた，シールフレームいずれの破面 にあ微細な割れが観察され，乙の破面を SEM/EDXに より元素分析した結果，硫黄が検出された。一方シーム 接合部から離れたふた中央部表面の SEM には異常は認 められなかった。なお割れ発生の傾向を示すと考えられ る気密度とピール強さの減少は, Table 3 亿示すとおり, 接合された直後よりも信頼性評価のため実施した熱サイ クル試験（208４23K，10サイクル）後の接合部におい て特に顕著に認められた。したがって割れ発生に対する 評価方法として，熱サイクル試験は有効な手段であると 考えられる。

このシーム接合部における割れ発生の原因を調べるた め剥離破断した表面の AES による元素分析を行った結 果, Fig. 4(d) に示すとおり硫黄のスペクトルが認められ た. 一方 EPMA による元素分析の結果, めっき凰に は,ふた, シールフレーム中の元素の混入は認められな かった．このため割れは，さきの SEM/EDX による 元素分析結果とあ合わせて考虑すれば, PGJ における調 査結果と同様に硫黄の粒界偏析が原因と考えられる。一 方ワット浴によりニッケルめっきされたふたを用いて気 密封止したパッケージのシーム接合部断面の光学顕微鏡 写真には, Fig. 8 に示すとおり割れの発生は認められ ず, また接合部を強制的に剥離破断した表面の SEM に おいてむ Fig. 6 と同様の延性破面を示し, 健全なシーム

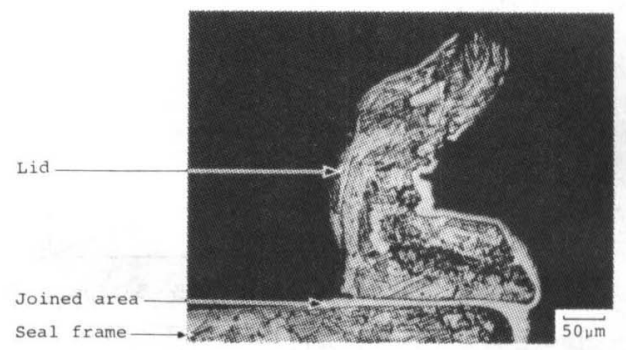

Fig. 9 Cross sectional microstructure of joint after peel test (Watts bath)

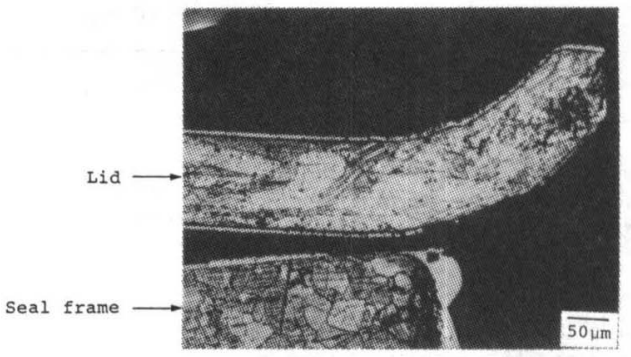

Fig. 10 Cross sectional microstructure of joint after peel test (Sulfamate bath)

接合部が得られたてとを裏付けている.

なお Table 3 において, *印で示したもののピール試 験における破断形態の一例を Fig. 9 に, また $\triangle$ 印で示し たものの一例を Fig. 10 に示す. Fig. 9 は気密度, ピール 強さともに満足すべき值を示す試料の断面写真である が，この写真から明らかなとおり，ふたはピール試験に より接合部近傍において引張応力により著しく変形し破 断しているにもかかわらず，接合部には異常はなく強固 なシーム接合状態にあることを示している。

一方 Fig. 10 は気密度試験においては $9 \times 10 \mathrm{~Pa} \mathrm{~m}^{3} / \mathrm{s}$ と良好な結果を示しているが，接合部近傍にはてれまで 示したような熱影響によるめっき層内の割れ発生が認め られる。そしてピール試験においては，乙の割れを起点 として非常に低い引張応力のもとで剥離が進行し, 接合 界面のめっき層において破断するため, ふたの変形は Fig. 9 と比較してほとんど琶められず，ピール強さは $30.4 \mathrm{~N}$ と著しく低い值を示した。この結果よりスルファ ミン酸浴を用いてニッケルぬっきされたふたを使用して 気密封止されたセラミックパッケージに関しては, 気密 度試験とピール試験の結果には相関関係のないことが明 らかになった。したがって MPSJ により気密封止され たパッケージの接合部に対する評価方法としては, 気密 度試験及びピール試験の両者を併用する必要がある。

次にこれまで観察されたスルファミン酸浴とワット浴 両者の浴組成の相違に基づく接合部の組織並びにピール 試験における破断形態の相違と，接合前のふたのめっき 組織との関係について調査した. Fig. 11(a) は, スルファ ミン酸浴による接合前のふたのニッケルめっき層の光学 顕微鏡写真であり，(b)はワット浴によるものである。乙 れらはいずれもふた端部のシーム接合に直接関係のある 部分を示しているが，乙の写真から明らかなとおり，前 


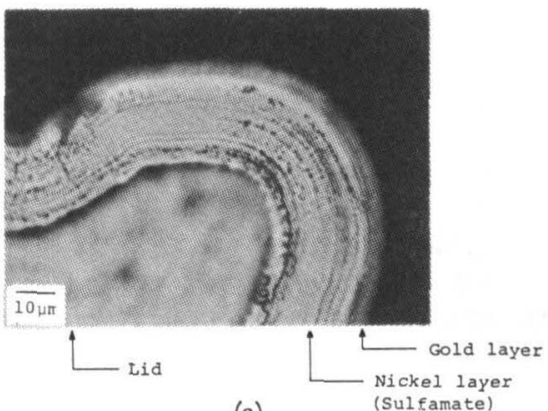

(a)

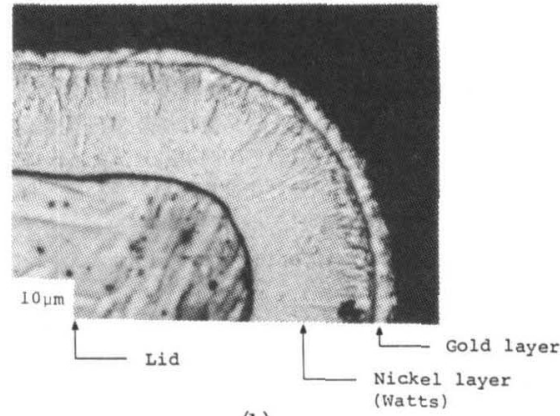

(b)

Fig. 11 Cross sectin sectional microstructures of nickel plating layer

(a) Sulfamate bath (b) Watts bath

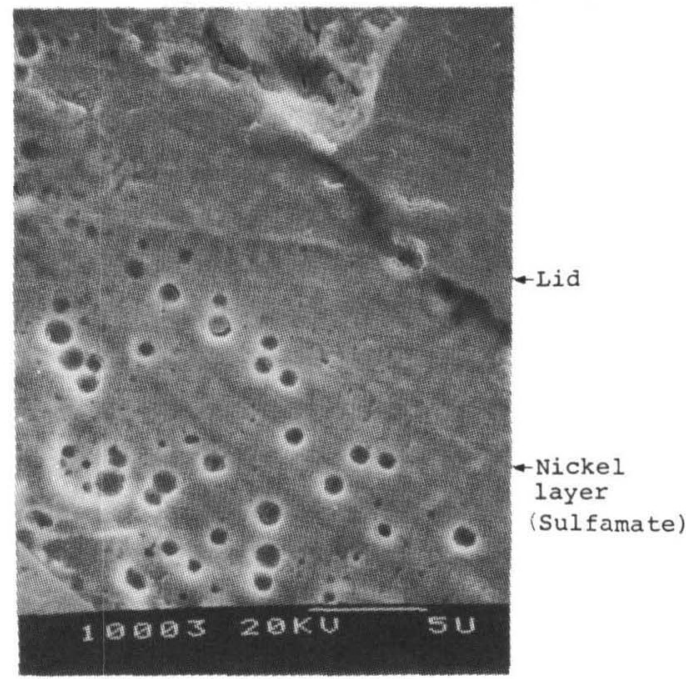

Fig. 12 Scanning electron micrograph of nickel plating layer (Sulfamate bath)

者は㟄状組織を示し, かつ黒い斑点状の介在物が認めら れる。一方後者は介在物のない柱状組織を示し, 両者の 組織の間には明瞭な差が慧められた。さらに Fig. 11(a) について SEM/EDX により拡大して元素分析を行った 結果, 黒い斑点状の介在物は直径が $0.5 \sim 1.0 \mu \mathrm{m}$ の球 状の硫黄の電析物であることが判明した (Fig.12 参照). まためっき層とふた素材の境界部の黒い部分からあ硫黄

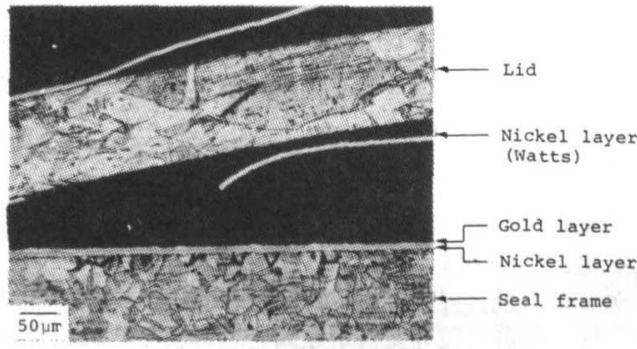

Fig. 13 Cross-sectional microstructure of peeled nickel plating layr layer (Watts bath)

が検出された．この硫黄は，さきに(1)式で示した反応の 結果電析したものと考えられ，また Fig. 4 に示した AES による各部分の元素分析結果を裹付けるむのであ る。一方 Fig. 11(a) の酋状組織についてあ SEM/EDX により元素分析を行ったが, 硫黄の電析物が連なる黒い 首とその中間の灰色の層との間には成分の差は認められ なかった，とれらの調査結果から，スルファミン酸浴に よりニッケルめっさされたふたの接合部において検出さ れた種々の欠陥の原因は, めっき凰中に斑点状に電析し た硫黄によるあのであることが明らかとなった．

以上の結果，七ラミックパッケージの気密封止に使用 されるふたのニッケルめっきにあたっては, めっき液と してスルファミン酸浴は不適当であり, ワット浴を使用 する必要のあるととが明らかとなった，しかしワット浴 においても $10 \mu \mathrm{m}$ の厚さにニッケルめっきされたふた については，Fig. 13 に見られるように接合部から少し 離れた部分において，めっき層がふた素材から完全に剥 離する現象が観察された。これは前述のとおり基本的に ワット浴によるニッケルめっきの内部応力が, スルファ ミン酸浴のそれと比較して約 2 倍大きいととに加えて, ニッケルめっきとふた素材の熱応力計算の結果，めっき 厚さが増加することにより，ふた素材における熱応力 (引張応力) がそれに比例して増加するため, 両者の界 面における剪断応力む増大してれが剝離の原因となった あのと考えられる8). したがってワット浴を使用してふ たのニッケルのめっきを行う場合には, $3.5 \mu \mathrm{m}$ 程度の 厚さが適当と考えられる.

なお本実験に使用しためっき液には, 光沢剤, 応力緩 和剤などの添加剤は一切使用しないととをさきに述べた が，これらの添加剤には硫黄を含有するあのが多いこと が報告されている9 。 したがってワット浴に対して内部 応力を緩和する目的で添加剤を使用すれば，乙れまで述 べた種々の接合部欠陥につながる可能性があるため，そ の使用にあたっては十分注意する必要がある.

\section{4. 結}

論

高信頼性 LSI 用セラミックパッケージの気密封止に 使用されるふた素材 ( $\mathrm{Fe}-\mathrm{Ni}-\mathrm{Co}$ 合金)を，ワット浴と スルファミン酸浴の両者によりニッケルめっきし, これ らを用いてまず PGJ により接合された接合部のめっ き組織とめっき浴組成との関係について調査し, 次に MPSJにより気密封止されたパッケージについて, 気密 度及び接合強さなどとめっき浴組成との関係について調 査した，その結果は次のとおりである。 
(1) スルファミン酸浴を用いてニッケルめっきされた 薄板と金めっきリボンを PGJ により接合した場合，游 板表面の二ッケルめっき圈には，硫黄の粒界偏析が原圆 と考えられる制れが発生した。一方ワット浴を用いた場 合，そのめっき序には異常はなく健全な接合部が得られ た。

(2) スルファミン酸浴を使用してニッケルめっきした ふたを用いて MPSJ により気密封止されたセラミック パッケージの接合界面におけるめっき圈には，PGJ の場 合之同様に硫黄の粒界倔析が原因と思われる割れが発生 した，そのため気密度，接合強さともに満足すべき結果 は得られなかった。

(3) ワット浴を用いてニッケルめっきしたふたを用い て MPSJ により紊密封止されたパッケージの接合界面 には割れの発生は認められず, 健全な接合組織を示し, 気密度，接合強さと屯に満足すべき結果が得られた。し かし $10 \mu \mathrm{m}$ の厚いめっきを施されたふたにおいては， 接合部から少し離れたふたの部分においてめっきの剥離 がみられた。したがってワット浴においては $3.5 \mu \mathrm{m}$ 程 度のめっき厚が適当と考えられる。

(4) 乙れらの結果から, 硫黄の供給源となるめっき浴 組成を含むめっき液の使用は, 接合部がめっき周を介し て形成される接合材料に対しては注意する必要がある。

(5) MPSJにより気密封止されたパッケージの接合部 におりる割れ発生の傾向は，接合直後よりも接合部の信 頼性評価のため実施した熱サイクル試験後の接合部にお いて特に顕著に惩められた，したがって割れ発生に対す る評価方法として，熱サイクル試験は有效な手段と若え られる。

(6) スルファミン酸浴を用いてニッケルめっきしたふ たを用いて MPSJ により気密封止されたパッケージに おいて，接合部の評価項目として実施した気密度とピー
ル強さとの間には相関関係は認められず，気密度は規格 做を満足してもピール強さはゼロあるいはそれに近い值 を示すすのがあった，したがって MPSJ により気密封 止されたパッケージの接合部に対する評価方法としては 両者を併用する必要がある。

謝 辞

本研究に対して有益なご意見，で討論を賜わった大阪 大学工学部，仲田周次教授に深く感謝致します。また SEM, EPMA，AES などの実験にご協力いただいた神 奈川罢工業試験所及び物日鐵テクノリサーチの関係各位 並びにめっき試料を作成していただいた野毛電気工業侏 の梅田泰氏に樑謝致します。

\section{参考文 献}

1) 青野ほか3名：接合界面におけるめつき層の存在と接合性への 影響ーマイクロパラレルシーム接合法及び接合機器の開発(第1 報)一溶接学会論文集，第4巻(1986)第 2 号. p.464 470

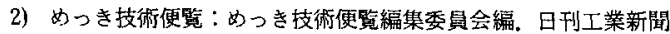
社. 昭和60年11月第8版

3) G, A DiBari;Nickel Plating Basics Part I, Metal Finishing. July 1986. p. $23 \sim 29$

4) MIL-STD - 883C Method 1014.6 Seal (25 August 1983)

5）志田ほか4名：母材のめっきがマイクロ溶接に及ほす影響(I)$\mathrm{Ni}$ ぬきと溶接性, 溶接学会全国大会講演概要第38集(1986-4), p.160 161

6)鈴木：鋼鉄材料研究におけるオージェ電子分析法の利用. 日本 金属学会会報. 第14巻(1975)第3号. p.173 185

7) A. F Greene; Anode Oxidation Products in Nickel Sulfamate Solutions, Plating. Vol.55. No.6(1968), p.594 599

8) 鶼户田, 川田, 倉西：材料力学 (上巻), 裳華堂

9) 例えば，G. A BiBari; Nickel Plating, Metal Finishing Guide. book Directory(1977), p.276 297 